\title{
Fungal Endophytes of Vitis vinifera-Plant Growth Promotion Factors
}

\author{
Markéta Kulišová ${ }^{1, *(1)}$, Maria Vrublevskaya ${ }^{1}$, Petra Lovecká ${ }^{2}$, Blanka Vrchotová $^{2}$, Milena Stránská ${ }^{3}$, \\ Miroslav Kolařík ${ }^{4}$ (i) and Irena Kolouchová ${ }^{1}$
}

1 Department of Biotechnology, University of Chemistry and Technology, Technická 5, 16628 Prague, Czech Republic; maria.vrublevskaya@vscht.cz (M.V.); irena.kolouchova@vscht.cz (I.K.)

2 Department of Biochemistry and Microbiology, University of Chemistry and Technology, Technická 5, 16628 Prague, Czech Republic; petra.lovecka@vscht.cz (P.L.); blanka.vrchotova@vscht.cz (B.V.)

3 Department of Food Analysis and Nutrition, University of Chemistry and Technology, Technická 5, 16628 Prague, Czech Republic; milena.stranska@vscht.cz

4 Institute of Microbiology, Academy of Sciences of the Czech Republic, Vídeňská 1083, 14220 Prague, Czech Republic; mkolarik@biomed.cas.cz

* Correspondence: marketa.kulisova@vscht.cz

check for updates

Citation: Kulišová, M.; Vrublevskaya, M.; Lovecká, P.; Vrchotová, B.; Stránská, M.; Kolařík, M.; Kolouchová, I. Fungal Endophytes of Vitis vinifera-Plant Growth Promotion Factors. Agriculture 2021, 11, 1250. https://doi.org/10.3390/ agriculture 11121250

Academic Editor: Ofir Degani

Received: 11 November 2021 Accepted: 9 December 2021 Published: 10 December 2021

Publisher's Note: MDPI stays neutral with regard to jurisdictional claims in published maps and institutional affiliations.

Copyright: (c) 2021 by the authors. Licensee MDPI, Basel, Switzerland. This article is an open access article distributed under the terms and conditions of the Creative Commons Attribution (CC BY) license (https:/ / creativecommons.org/licenses/by/ $4.0 /)$.

\begin{abstract}
Endophytes are microorganisms that live asymptomatically inside plant tissues. They are beneficial to their host in many aspects, especially as a defense against foreign phytopathogens through the production of a variety of metabolites. These substances can serve as sources of new natural products for medicinal, agricultural, and industrial purposes. This article is focused on endophytic fungi from Vitis vinifera. The purpose of the research was their isolation and identification during the Vitis vinifera growing season. Subsequently, the isolates were tested for the production of biotechnologically interesting metabolites (siderophores, antioxidants, and antifungal compounds). In total, 24 endophytic fungi were isolated, the most represented genus was Cladosporium sp. The results of the test for antioxidant and antifungal properties, as well as siderophore production, have shown that the population of Vitis vinifera endophytic microscopic fungi could serve as a promising source of metabolites with a wide range of applications.
\end{abstract}

Keywords: microscopic fungi; endophytes; Vitis vinifera; antifungal activity; antioxidants; siderophores

\section{Introduction}

The grapevine (Vitis vinifera) is one of the most economically important crops, being used mainly for wine production (approximately 80\% of harvested wine grapes is used for this purpose). Grapes and other parts of Vitis vinifera contain a number of health promoting metabolites [1]. As with other plants, the tissues of the grapevine are inhabited by various types of microorganisms. These organisms can be epiphytic, i.e., superficial, or colonizing internal tissues, i.e., endophytic [2]. The interactions between endophytes and their plant hosts are diverse. Plants provide protection and endophytic microorganisms are capable of producing useful metabolites that increase nutrient uptake, induce resistance to pathogens, increase tolerance to osmotic stress, heavy metals, xenobiotic contaminants, and other forms of abiotic stress [3]. Most endophytes are represented by bacteria, but microscopic fungi and yeasts also form a significant part of the endophytic population. Endophytes are isolated from a variety of plant species, and almost all studied plant species have been found to host at least one endophytic microorganism [4]. Colonization of the host plant with up to a hundred different species is no exception. Geographic location, season, climate, and type of plant tissue are among the factors that affect species composition and frequency of endophyte colonization [5,6].

Endophytes act as important sources of structurally unique bioactive natural metabolites with a wide biotechnological potential. They represent an attractive source of natural products that can be used in agriculture, industry, and medicine [7-13]. The formation of 
antibacterial, antifungal, antiviral, cytotoxic, and immunosuppressive metabolites, as well as antioxidants and siderophores, has been previously found [14,15]. Nowadays, when new diseases caused by microorganisms are emerging and resistance to known drugs is spreading, it is the siderophores of a relatively poorly studied endophytic population that can be used to develop active substances in the pharmaceutical industry [16].

Several researchers have recently investigated grapevine fungal endophytes to clarify their diversity and ecological role in this plant. The use of chemicals as fertilizers in agriculture, endophytes producing antibacterial and antifungal compounds could be an interesting alternative to these active substances. Phoma glomerata, Chaetomium globosum, Aureobasidium pullulans, Epicoccum nigrum, and Acremonium spp. have repeatedly exhibited antibacterial and antifungal properties effective against a number of plant diseases [6,17-22]. Alternaria alternata and Fusarium proliferatum have also been identified as promising biocontrol agents against specific pathological conditions of Vitis vinifera, such as grapevine downy mildew caused by Plasmopara viticola $[6,22,23]$.

Resveratrol, as an antioxidant compound known to increase resistance to stress and prolong the life of a variety of organisms, from yeasts to vertebrates, is abundant in $\mathrm{Vi}$ tis vinifera grapes. Many endophytes show the ability to produce the same functional compounds as their hosts while living asymptomatically in plant tissues. Fungal endophytes capable of resveratrol production include Penicillium, Aspergillus, Mucor, Alternaria, Cephalosporium, and Geotrichum. Alternaria species appear to be the best producers due to the stable production of resveratrol [24]. The research work of Yang et al. [25] investigated the role of endophytes in the formation of secondary metabolites (total flavonoids and resveratrol) and the influence of physio-chemical traits in grapes and leaves. Fungal endophytes originally isolated from Vitis vinifera were re-inoculated on growing grapevine plants and their effect on grapes and leaves was evaluated. This inoculation increased the content of reducing sugar, total flavonoids, polyphenols, and trans-resveratrol in particular parts of Vitis vinifera. Nigrospora sp. and Fusarium sp. appeared to be the most promising of the fungal genera studied.

The aim of our study was to isolate and characterize the endophytic fungi that occur in Vitis vinifera leaves, canes, and berries grown in vineyards within the Czech Republic. Another goal was to investigate their potential to act as plant growth promoters and disease protective agents. This was done by testing their ability to produce antioxidants, siderophores, and antifungal compounds.

\section{Materials and Methods}

\subsection{Samples}

Samples of Muller Thurgau, Pinot Gris, Pinot Noir and Riesling Rheinhessen grapevine varieties were collected from two different vineyards within the Czech Republic, Kutna Hora $(49.9336 \mathrm{~N}, 15.2889 \mathrm{E}$; grapevine grown according to the principles of organic farming) and Prague (50.0690 N, 14.4454 E; conventionally grown grapevine). Three different experimental plants located at different sites within the vineyards were selected for continuous sampling during the entire vegetation year. The sampling of leaves and canes as lignified stems of the plants was carried out in January, May, August and October 2019 in approximate amounts between 3 and $10 \mathrm{~g}$ of leaves, depending on the sampling season (leaves were not sampled in January due to their fall during the autumn), and canes were collected in approximate amounts of $50 \mathrm{~g}$. Berries were sampled in September 2019 in an amount of $500 \mathrm{~g}$, only from the Prague vineyard (strong storms in Kutna Hora region ruined the crops and sampling was not possible). The samples were stored at $-80{ }^{\circ} \mathrm{C}$ before processing in the laboratory. Characterization of the samples from which were fungal endophytes is provided in Table 1. 
Table 1. Characterization of Vitis vinifera leaves/canes/berries from which fungal endophytes were isolated.

\begin{tabular}{|c|c|c|c|c|}
\hline Sample Code & Sampling Period & Grapevine Variety & Plant Part & $\begin{array}{l}\text { Growing Locality } \\
\text { (Farming System) }\end{array}$ \\
\hline Z-MT-G-S6 & January 2019 & Muller Thurgau & canes & Prague (conventional) \\
\hline Z-RR-G-S & January 2019 & Riesling Rheinhessen & canes & Prague (conventional) \\
\hline Z-MT-KH-S1 & January 2019 & Muller Thurgau & canes & Kutna Hora (organic) \\
\hline Z-MT-KH-S2 & January 2019 & Muller Thurgau & canes & Kutna Hora (organic) \\
\hline Z-RM-KH-S1 & January 2019 & Pinot Noir & canes & Kutna Hora (organic) \\
\hline Z-RM-KH-S2 & January 2019 & Pinot Noir & canes & Kutna Hora (organic) \\
\hline J-MT-G-L2 & May 2019 & Muller Thurgau & leaves & Prague (conventional) \\
\hline J-RR-G-S2 & May 2019 & Riesling Rheinhessen & canes & Prague (conventional) \\
\hline J-RS-KH-L1 & May 2019 & Pinot Gris & leaves & Kutna Hora (organic) \\
\hline J-RS-KH-L2 & May 2019 & Pinot Gris & leaves & Kutna Hora (organic) \\
\hline J-MT-KH-S4 & May 2019 & Muller Thurgau & canes & Kutna Hora (organic) \\
\hline J-RM-KH-S3 & May 2019 & Pinot Noir & canes & Kutna Hora (organic) \\
\hline J-RM-KH-S4 & May 2019 & Pinot Noir & canes & Kutna Hora (organic) \\
\hline J-RM-KH-S5 & May 2019 & Pinot Noir & canes & Kutna Hora (organic) \\
\hline J-RR-KH-S2 & May 2019 & Riesling Rheinhessen & canes & Kutna Hora (organic) \\
\hline J-RR-KH-S3 & May 2019 & Riesling Rheinhessen & canes & Kutna Hora (organic) \\
\hline L-MT-KH-L5 & August 2019 & Muller Thurgau & leaves & Kutna Hora (organic) \\
\hline L-RS-KH-L4 & August 2019 & Pinot Gris & leaves & Kutna Hora (organic) \\
\hline L-RR-KH-L4 & August 2019 & Riesling Rheinhessen & leaves & Kutna Hora (organic) \\
\hline L-RM-KH-S6 & August 2019 & Pinot Noir & canes & Kutna Hora (organic) \\
\hline P-RM-G-L1 & October 2019 & Pinot Noir & leaves & Prague (conventional) \\
\hline P-RS-G-S2 & October 2019 & Pinot Gris & canes & Prague (conventional) \\
\hline P-MT-KH-L7 & October 2019 & Muller Thurgau & leaves & Kutna Hora (organic) \\
\hline P-RM-KH-L7 & October 2019 & Pinot Noir & leaves & Kutna Hora (organic) \\
\hline MT-M1 & September 2019 & Muller Thurgau & berries & Prague (conventional) \\
\hline MT-M4 & September 2019 & Muller Thurgau & berries & Prague (conventional) \\
\hline RR-M1 & September 2019 & Riesling Rheinhessen & berries & Prague (conventional) \\
\hline RR-M2 & September 2019 & Riesling Rheinhessen & berries & Prague (conventional) \\
\hline RS-M2 & September 2019 & Pinot Gris & berries & Prague (conventional) \\
\hline
\end{tabular}

\subsection{Fungal Endophytes Isolation and Cultivation}

The plant material was surface sterilized by sequential immersion in $0.625 \%$ aqueous sodium hypochlorite with a drop of Tween $80(7 \mathrm{~min})$, followed by $70 \%$ aqueous ethanol ( $3 \mathrm{~min}$ ). After these procedures, the samples were rinsed four times with sterilized water (15 min). The surface-sterilized tissues were homogenized and used to inoculate YGC medium (yeast extract glucose chloramphenicol agar) and incubated at $20{ }^{\circ} \mathrm{C}$ for $72 \mathrm{~h}$ or more.

\subsection{Molecular Genetic Identification of Endophytes}

Genomic DNA was isolated from pure fungus culture by using the ArchivePure DNA Yeast and Gram- + Kit (5 PRIME, Hamburg, Germany). Subsequently, the nuclear ribosomal ITS1-5, 8S-ITS2 region was determined for all strains according to Kolařík et al. [26]. Due to the low resolution of the ITS region in some fungal species, the sequencing of other sections was made to clarify the identification. Elongation factor 1 alpha $(\mathrm{EF} 1 \alpha)$ was amplified and sequenced using primers EF-728F/EF-986R and EF1-983F/EF1-2218R according to Kolařík et al. [26]. The partial $\beta$-tubulin (TUB2) gene was amplified using T1/T2 according to Píchová et al. [27]. The sequences obtained were manually cut from unreadable sections and the highest probability of the acquired sequence was searched in the GenBank database.

\subsection{Determination of Siderophores Production of the Isolates}

The method of Marques et al. [28] was followed to determine siderophore production. Fungal cultures were inoculated on Chrome azurol S (CAS) agar, and cultivated at $28^{\circ} \mathrm{C}$ for 7 days. After cultivation, the color change (blue to yellow) was evaluated and scaled 
( 0 = blue medium surface, no siderophore production; $1=30 \%$ yellow medium surface - low siderophore production; $2=60 \%$ yellow medium surface-medium siderophore production, 3 = yellow medium surface, high siderophore production (Figure 1.)).



Figure 1. Fungal endophyte cultured on CAS agar with high siderophore production activity (color change from blue to yellow).

\subsection{Determination of Antioxidant Activity of the Isolates}

The fungal endophyte isolates were grown in PDB medium at $30{ }^{\circ} \mathrm{C}$ for 7 days with constant shaking. The antioxidant activity of the supernatant of the filtered culture was determined according to Fidler and Kolářová [29]. The analyses were performed on the microtiter plates in three parallels for each sample. An aliquot of $100 \mu \mathrm{L}$ of the sample was pipetted together with $200 \mu \mathrm{L}$ of DPPH at a concentration of $52 \mathrm{mg} \mathrm{L}^{-1}$ (in methanol) in the wells. Distilled water was used as a blank. The plate was incubated in the dark for $15 \mathrm{~min}$. The absorbance was measured at $517 \mathrm{~nm}$. The results of the analysis were expressed as the percent decrease in the discoloration of the solution against the blank. The results were expressed as an ascorbic acid (AA) equivalent, which was chosen as an analytical standard in the concentration range of $2.5-25 \mathrm{mg} \mathrm{L}^{-1}$.

\subsection{Determination of Antifungal Activity of the Isolates}

Antifungal activity was tested on PDA agar according to Bell et al. [30]. Two wells ( $7.5 \mathrm{~mm}$ diameter) were excavated in the agar at the same distance from the center. One of the wells was filled with agar with a grown fungal endophyte and the other with agar containing a fungal phytopathogen. These plates were cultivated at $28{ }^{\circ} \mathrm{C}$ for 7 days. Testing was carried out with three fungal phytopathogens-Botrytis cinerea DBM 1246, Fusarium solani CCF 2967, and Mucor plumbeus CCF 2626. The phytopathogenic culture itself served as a control sample. Antifungal activity was displayed by slowing or stopping the growth of a fungal phytopathogen in the vicinity of the growth of an endophytic fungus. The degree of fungal antagonism was evaluated on a scale of 5-1 (5-the endophyte completely outgrows the phytopathogen; 4 -the endophyte colonizes $2 / 3$ of the medium surface; 3 - the endophyte and the phytopathogen both colonize half of the medium surface (Figure 2); 2-phytopathogen colonizes 2/3 of the medium surface; 1 -the phytopathogen completely outgrows the endophyte).

\subsection{Statistical Analysis}

Dixon's $Q$ test was performed to detect outliers in datasets obtained by the determination of antioxidant activity (the determination was performed in five parallels. The deviation of the five determinations was less than $5 \%$ ). The determination of ability to produce siderophores and antifungal activity was performed in three parallels. 


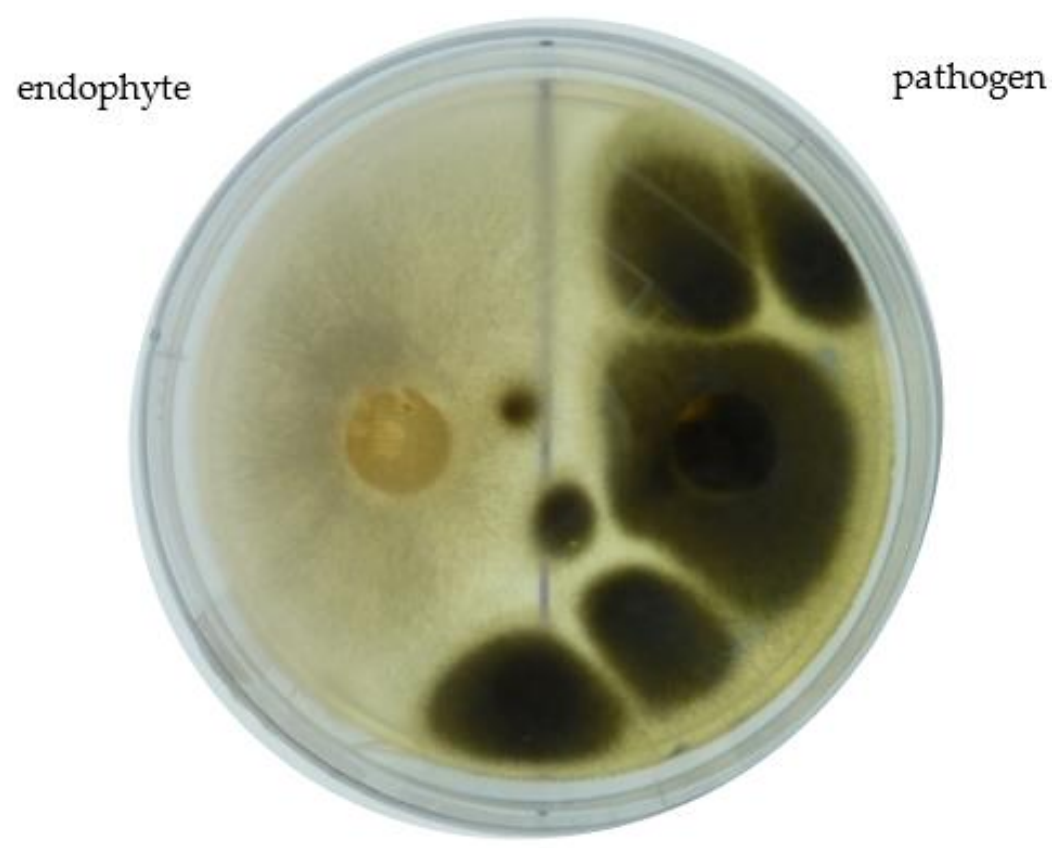

Figure 2. Fungal endophyte with the degree of antagonism of level ' 3 ' to phytopatogen (colonization of half of the medium surface).

\section{Results}

\subsection{Fungal Endophytes Characterization and Molecular Genetic Identification}

For canes and leaves, a total of 24 endophytic microscopic fungi belonging to 14 fungal genera were isolated from both vineyards. Six isolates were obtained during the winter from both conventional and organic farming localities, ten isolates were obtained from the spring collection, with the majority of endophytes originating from organically grown plants, four fungal endophytic species were isolated from summer samples from the organic farming region, and four isolates came from the autumn sampling, from both farming system localities. The genus Cladosporium was represented by two species, Cladosporium cladosporioides and Cladosporium herbarum. The further more represented genera were Didymella sp., Aspergillus sp., Aureobasidium sp. and Alternaria sp. All five isolates obtained from the berries belong to Penicillium sp., specifically to the species Penicillium cructosum (for details, see Table 2).

\subsection{Production of Siderophores}

Siderophore production was established for $83 \%$ of isolates from the winter biomass collection, in $60 \%$ of isolates from the spring sampling, in $75 \%$ of isolates from summer, in $50 \%$ of fungal endophytes species being isolated from autumn leaves and cane samples, and in all endophytes isolated from berries. The highest ability to produce siderophores (degree ' 3 ') was detected for endophytes from winter sampling and organically grown canes, in particular for Diatrype stigma (Z-MT-KH-S1 isolate) and Aspergillus niger (Z-RM$\mathrm{KH}-\mathrm{S} 2$ isolate), and for endophytes originating from berries, i.e., Penicillium crustosum (MT-M4 isolate, RR-M2 isolate, RS-M2 isolate).

Isolates J-MT-G-L2 (Epicoccum nigrum), J-RS-KH-L2 (Dendrophoma juglandina) and J-RR-KH-S3 (Neosetophoma shoemakeri) from spring sampling showed the medium ability to produce siderophores (degree ' 2 '), the highest one for the given period. Regarding the summer and autumn sampling, all isolates had low or zero siderophore production ability (degree ' 1 ' or ' 0 '), with the exception of the three above-mentioned isolates from berries. The details are summarized in Table 2. 
Table 2. The species of fungal endophytes isolated from canes, leaves and berries taxonomy identification, together with biological activities of particular isolates.

\begin{tabular}{|c|c|c|c|c|c|c|c|}
\hline \multirow[t]{2}{*}{ Sample Code ${ }^{1}$} & \multirow{2}{*}{$\begin{array}{l}\text { Sample } \\
\text { Matrix }\end{array}$} & \multirow{2}{*}{$\begin{array}{c}\text { Endophyte Species } \\
\text { Taxonomy }\end{array}$} & \multirow{2}{*}{$\begin{array}{c}\text { Ability to } \\
\text { Produce } \\
\text { Siderophores }\end{array}$} & \multirow{2}{*}{$\begin{array}{c}\text { Antioxidant } \\
\text { Activity } \\
\left(\mathrm{mg}_{\mathrm{AA}} \mathrm{L}^{-1}\right)\end{array}$} & \multicolumn{3}{|c|}{ Antifungal Activity ${ }^{3}$ to: } \\
\hline & & & & & $\begin{array}{l}\text { Botrytis } \\
\text { cinerea }\end{array}$ & $\begin{array}{l}\text { Fusarium } \\
\text { solani }\end{array}$ & $\begin{array}{c}\text { Mucor } \\
\text { plumbeus }\end{array}$ \\
\hline Z-MT-G-S6 & canes & $\begin{array}{l}\text { Cladosporium } \\
\text { cladosporioides }\end{array}$ & 1 & 12.4 & 2 & 2 & 2 \\
\hline Z-RR-G-S & canes & Alternaria arborescens & 0 & 13.8 & 3 & 2 & 3 \\
\hline Z-MT-KH-S1 & canes & Diatrype stigma & 3 & 17.5 & 2 & 2 & 2 \\
\hline Z-MT-KH-S2 & canes & Didymella negriana & 0 & 4.8 & 3 & 2 & 2 \\
\hline Z-RM-KH-S1 & canes & $\begin{array}{c}\text { Aspergillus } \\
\text { pseudodeflectus }\end{array}$ & 2 & 21.8 & 3 & 3 & 2 \\
\hline Z-RM-KH-S2 & canes & Aspergillus niger & 3 & 13.4 & 2 & 4 & 4 \\
\hline J-MT-G-L2 & leaves & Epicoccum nigrum & 2 & 17.6 & 3 & 3 & 2 \\
\hline J- RR-G-S2 & canes & Pleurophoma ossicola & 0 & 2.7 & 2 & 3 & 3 \\
\hline J-RS-KH-L1 & leaves & Sporocadus rosigena & 1 & 6.6 & 3 & 3 & 2 \\
\hline J-RS-KH-L2 & leaves & Dendrophoma juglandina & 2 & 0 & 2 & 2 & 2 \\
\hline J-MT-KH-S4 & canes & $\begin{array}{c}\text { Pseudogymnoascus } \\
\text { pannorum }\end{array}$ & 0 & 0 & 2 & 3 & 2 \\
\hline J-RM-KH-S3 & canes & Aureobasidium pullulans & 1 & 6.4 & 2 & 2 & 2 \\
\hline J-RM-KH-S4 & canes & Didymella sancta & 1 & 8.3 & 2 & 2 & 2 \\
\hline J-RM-KH-S5 & canes & Cladosporium herbarum & 0 & 7.5 & 3 & 3 & 2 \\
\hline J-RR-KH-S2 & canes & Phaeosphaeriaceae sp. & 0 & 7.8 & 2 & 2 & 2 \\
\hline J-RR-KH-S3 & canes & Neosetophoma shoemakeri & 2 & 6.7 & 2 & 3 & 3 \\
\hline L-MT-KH-L5 & leaves & Aspergillus fumigatus & 1 & 9.3 & 2 & 4 & 3 \\
\hline L-RS-KH-L4 & leaves & Lophiostoma corticola & 1 & 8.3 & 4 & 1 & 1 \\
\hline L-RR-KH-L4 & leaves & Cladosporium herbarum & 0 & 8.1 & 2 & 3 & 2 \\
\hline L-RM-KH-S6 & canes & Aureobasidium pullulans & 1 & 0 & 3 & 3 & 2 \\
\hline P-RM-G-L1 & leaves & Alternaria astroemeriae & 0 & 7.5 & 3 & 3 & 2 \\
\hline P-RS-G-S2 & canes & Aureobasidium pullulans & 1 & 7.1 & 3 & 3 & 2 \\
\hline P-MT-KH-L7 & leaves & Cladosporium herbarum & 0 & 0 & 1 & 1 & 1 \\
\hline P-RM-KH-L7 & leaves & Didymella sancta & 1 & 3.4 & 3 & 3 & 3 \\
\hline MT-M1 & berries & Penicillium crustosum & 1 & 10.5 & 3 & 3 & 2 \\
\hline MT-M4 & berries & Penicillium crustosum & 3 & 9.3 & 4 & 5 & 2 \\
\hline RR-M1 & berries & Penicillium crustosum & 1 & 13.9 & 2 & 3 & 2 \\
\hline RR-M2 & berries & Penicillium crustosum & 3 & 23.9 & 4 & 5 & 3 \\
\hline RS-M2 & berries & Penicillium crustosum & 3 & 19.1 & 4 & 5 & 2 \\
\hline
\end{tabular}

Bold formatting values-high ability to produce siderophores, or high antioxidant activity or high antifungal activity; ${ }^{1}$ See Table 1. for sample characterization; ' ' 0 ' - no siderophore production; ' 1 '-low siderophore production; ' 2 ' - medium siderophore production, ' 3 '-high siderophore production; ${ }^{3}$ Degree of antagonism: 5-the endophyte completely outgrows the phytopathogen; 4-the endophyte colonizes $2 / 3$ of the medium surface; 3 - endophyte and phytopathogen colonize each $\frac{1}{2}$ of the medium surface; 2 - phytopathogen colonizes $2 / 3$ of the medium surface; 1 - the phytopathogen completely outgrows the endophyte.

\subsection{Antioxidant Activity}

The ability to produce antioxidants into the medium was identified in all endophytes isolated from winter canes, in $80 \%$ of endophytes isolated from the spring biomass collection, in $75 \%$ of isolates originating from the summer and autumn $V$. vinifera biomass, and in all of the isolates from berries. The content of antioxidants expressed as ascorbic acid (AA) equivalent was determined in the range of $4.8-21.8 \mathrm{mg}_{\mathrm{AA}} \mathrm{L}^{-1}$ for the winter isolates, $0-17.6 \mathrm{mg}_{\mathrm{AA}} \mathrm{L}^{-1}$ for the spring isolates, $0-9.3 \mathrm{mg}_{\mathrm{AA}} \mathrm{L}^{-1}$ for the summer isolates, 0-7.5 mg $\mathrm{AA} \mathrm{L}^{-1}$ for the autumn endophytes from leaves and canes and 9.3-23.9 $\mathrm{mg}_{\mathrm{AA}} \mathrm{L}^{-1}$ for the autumn isolates from berries. The endophytes with the highest antioxidant production were isolates from berries, i.e., Penicillium crustosum (RR-M2 isolate and RS-M2 isolate), with 23.9 and $19.1 \mathrm{mg}_{\mathrm{AA}} \mathrm{L}^{-1}$, respectively, and Aspergillus pseudodeflectus (Z-RM-KH-S1 isolate) from winter organically farmed canes $\left(21.8 \mathrm{mg}_{\mathrm{AA}} \mathrm{L}^{-1}\right)$. For details, see Table 2.

\subsection{Antifungal Activity}

The highest degree of antagonism, level ' 5 ' explaining the highest antagonism where the endophyte completely outgrows the phytopathogen, was against $F$. solani and was observed for 
Penicillium crustosum (MT-4, RR-M2, RS-M2) isolated from berries. All these three endophytic isolates also showed significant antifungal activity against $B$. cinerea (level ' 4 ').

The other relatively strong antagonist of $B$. cinerea DBM 4111 was the endophyte Lophiostoma corticola (L-RS-KH-L4) isolated from organically grown leaves collected in summer. For the phytopathogen F. solani CCF 2967, the other highly effective endophytes were Aspergillus niger (Z-RM-KH-S2) isolated from organically farmed winter canes and Aspergillus fumigatus (L-MT-KH-L5) isolated from organically farmed summer leaves. For Mucor plumbeus CCF 2626, the highest antagonist was Aspergillus niger (Z-RM-KH-S2) isolated from organically grown winter canes. For details, see Table 2.

\section{Discussion}

Recently, endophytic microorganisms and their products have been attracting the attention of the scientific community as a relatively poorly understood source of a wide range of chemically diverse natural substances potentially usable in biotechnology, pharmaceutical and food industry. The increased attention for studying endophytic populations is based on the desire to produce non-chemical based solutions. Comparing endophytic populations in-situ in terms of the presence of individual microorganisms or the formation of their metabolites is challenging due to the many factors (altitude, temperature, total precipitation, rhizosphere composition, or pesticide use) that affect these populations. Despite this, the methods for testing the endophytic isolates in laboratory conditions are well established.

\subsection{Fungal Endophytes Characterization and Molecular Genetic Identification}

Another degree of variability in the endophyte composition is the physiological state of the host plant itself, its growth phase, and the tissue from which the sample is taken. Thus, even isolates from the same geographical location may be diametrically different [31-34]. This variability was confirmed in this work, where isolates of fungal endophytes from two vineyards of different farming systems were examined. The Kutna Hora vineyards grow grapevines according to the principles of organic farming, and the Prague vineyards grow their grapevines in a conventional way. The total number of fungal endophytes isolated from canes and leaves from organically grown plants was approximately three times higher than the number of endophytes isolated from conventional vineyards, which is consistent with previous studies $[35,36]$. This difference could be related to the use of chemical or organic fertilizers and herbicides that directly affect microorganisms or alter the physiology of the host plant $[37,38]$. The response of endophytic microbial communities to these external products is very beneficial for comparing organic and conventional agriculture, and further research could go in this direction.

Precipitation is one of the main abiotic factors that affect the density of endophytes in the host plant [39-41]. The proportion of endophytes in the leaves of trees that have been protected from rain is lower than in the leaves of identical trees, but unprotected from rainfall. Suryanarayanan et al. dealt with this issue in the rainforest environment during the rainy season and drought. In all tested leaf samples of Bauhinia racemosa, Ixora nigricans, Erythroxylon monogynum and Elaeodendron glaucum, an increased representation of the endophytic community was detected during the rainy season [40]. The more abundant colonization of plants by fungal microorganisms at higher precipitation rates may be related to the consequent increased number of endophytes in the host plant. Precipitation is also one of the major types of endophytic spore transmission. So far, there is a little information on where endophyte spores are produced, where they can hibernate and what the mode of transmission is. R. parkeri sporulates prolifically on Contarinia midge galls on Douglas fir needles, and there were measured 1200 spores $/ \mathrm{mL}$ in water dripping from a heavily galled branchlet. $R$. parkeri and its anamorph also sporulate in the fall in abscised needles. The spore masses of this endophyte are produced in mucilage, which is indicative of water transmission. Further, newly flushed needles in the spring do not become infected until they are rained on in the fall. From these findings we could suggest that the association 
between higher endophyte counts and moisture is not accidental [41]. If we follow the number of cane and leaf isolates obtained from individual periods of the Vitis vinifera growing year, the predominance of spring sampling is evident (Table 1.). May 2019 (spring sampling) was well above the long-term precipitation average. August 2019 (summer sampling) was only slightly below this average and October 2019 (autumn sampling) was quite average, which corresponds to a lower endophytic proportion (Figure 3). However, heavy rain and storms could completely destroy the grapevine crop, which unfortunately occurred in autumn 2019 in the Kutna Hora vineyards. These natural phenomena made the sampling of berries from this biodynamic vineyard in September 2019 impossible.

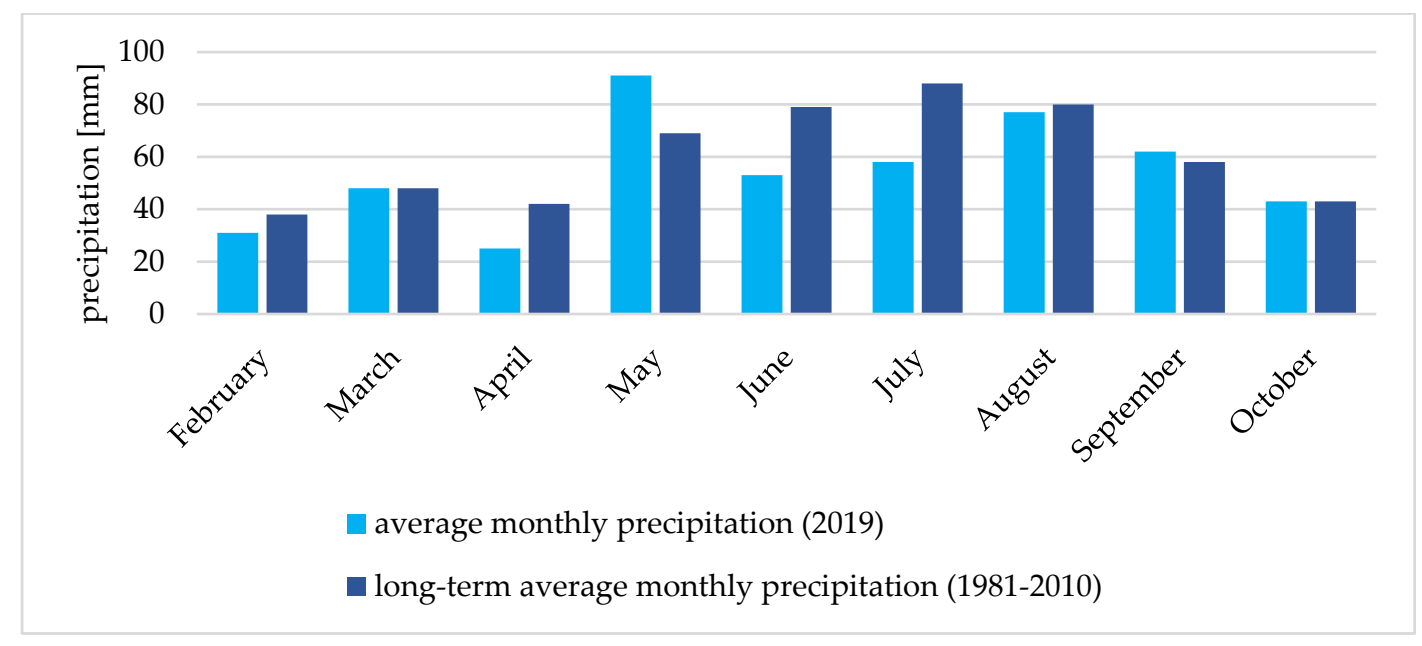

Figure 3. Average precipitation from February 2019 to October 2019 compared to the long-term average (1981-2010) (data from the Czech Hydrometeorological Institute).

The amplification of ITS rDNA and subsequent comparison of the obtained sequence with the database is currently the most widely used method for the identification of fungal endophytes [42,43]. All 29 isolates belonging to 15 genera were successfully identified, and all of them belonged to the Ascomycota phylum. This phylum significantly predominates in the proportion of fungal endophytes in Vitis vinifera, regardless of the geographical location of the host plant $[34,44]$. The most abundant genera were Penicillium sp., Cladosporium sp., Didymella sp., Aspergillus sp., Aureobasidium sp., and Alternaria sp. Alternaria sp. and Cladosporium sp. are one of the most abundant endophytes of Vitis vinifera [34,43], which is in accordance with our results.

\subsection{Production of Siderophores}

Siderophores have received great attention in medicine, biotechnology, and environmental research due to their high affinity and specificity for $\mathrm{Fe}^{3+}$. The only fungal endophyte isolates from canes and leaves with a high ability to produce siderophores came from the winter period of 2019. The ability to form these compounds has been declining since winter, with only low or zero production activity in summer and autumn. The highest result of siderophore production in winter can be explained by the reduced movement of nutrients in the soil due to low temperatures and therefore iron deficiency in both the endophyte and the host plant and the increased need for uptake of these nutrients by other mechanisms [45]. Diatrype stigma and Aspergillus niger were isolates with the highest detected siderophore production activity. In this paper, the production of siderophores by the genus Diatrype was proved for the first time. With regard to the high activity of production of these compounds identified, it would be interesting to pay further attention to the species of this microbial genus in the research. Aspergillus species are well-researched producers of siderophores, serving as a model organism to elucidate the biosynthesis, absorption, and degradation of these secondary metabolites [46]. Three berry isolates also showed a high ability to produce siderophores. All of these isolates belong to Penicillium 
crustosum, which is in agreement with the findings in the literature that this genus is capable of siderophore production [47]. In a study on the characterization of siderophores produced by endophytes from Cymbidium aloifolium, the genus Penicillium was found to be the best producer of these compounds [48].

\subsection{Antioxidant Activity}

There is growing evidence of oxidative damage to biomolecules by free radicals. These injuries could cause much tissue harm. Antioxidants are considered highly effective in defending tissue against damage caused by reactive oxygen species [49]. Fungal endophytes can be a potentially very good source of antioxidants [50] which has been confirmed in isolates in this study. The isolate with the highest antioxidant activity $\left(21.7 \mathrm{mg}_{\mathrm{AA}} \mathrm{L}^{-1}\right)$ of canes and leaves was Aspergillus pseudodeflectus. Arora and Chandra [51] investigated the antioxidant activity of the genus Aspergillus, specifically Aspergillus fumigatus. The data have shown that this microorganism can serve as a promising source of antioxidant compounds. Our results show an even higher antioxidant activity for the fungal endophyte Aspergillus pseudodeflectus than was mentioned in the article. Other studies also mention the high antioxidant activity of endophytes of Aspergillus sp. and the possibilities of further use of these properties [52,53]. Therefore, this fungal genus could serve to more easily adjust the production and purification of natural antioxidants.

Penicillium is another fungal endophytic genus studied in more detail with high antioxidant activity [7,54]. In berries, two of the Penicillium crustosum isolates showed high antioxidant activity ( 23.9 and $19.1 \mathrm{mg}_{\mathrm{AA}} \mathrm{L}^{-1}$ ) which is in connection with previous studies $[7,55,56]$. Other fungal endophytes with high antioxidant activity are Fusarium sp. [57,58] and Burkholderia phytofirmans [59]. In other study, fungal endophytes Diaporthe sp., Colletotrichum sp., and Arthinium sp tend to generate a wide array of bioactive compounds ( $\beta$-dihydro agarofuran, $\alpha$-agarofuran, $\delta$-eudesmol, $\beta$-agarofuran, and oxoagarospirol) with strong antioxidant activity [60]. According to Hamilton and Bauerle, the antioxidant activity in plants with endophytes under abiotic stress is higher than in plants without these microorganisms [61].

In general, the proportion of genera with antioxidant activity in Vitis vinifera is relatively high, which correlates with the assumption of the formation of similar secondary metabolites between the host plant and its endophytes. Grapevine itself is an important source of antioxidants, especially phenolic substances.

\subsection{Antifungal Activity}

The fungal endophytes of Vitis vinifera could have an antagonistic effect on some important phytopathogens. Studies mapping this antifungal ability of endophytic communities are essential to shape pest control strategies but also to potential production of high-quality agricultural products. In the case of grapevine, one of its most common pathogens is the fungus Botrytis cinerea, which causes Botrytis bunch rot. The most effective antifungal agents against this phytopathogen are the endophytes Alternaria sp. and Epicoccum sp. Both are also promising biocontrol agents against Plasmopara viticola, another important source of Vitis vinifera diseases [34]. The antifungal ability found against Botrytis cinerea in Alternaria and Epicoccum isolates in this research work was expressed by the degree of antagonism at level ' 3 ', which could be expressed as $50 \%$. The mentioned genera did not show above average activity even against the other two tested phytopathogens Fusarium solani and Mucor plumbeus. Fusarium solani is an important plant pathogen that most often causes rot in the root system. It has the ability to penetrate cell walls and therefore cause plant tissue to rot [62]. Mucor plumbeus is associated with the growth of fungi in cereals, rice, soybeans, nuts, fruits, herbs, and others [63].

The highest degree of antagonism (level ' 4 ') against Botrytis cinerea was detected in isolates from canes and leaves in only one endophyte, Lophiostoma corticola. This is the first paper to show the ability of this fungus to produce antifungal compounds. The ability of the Lophiostoma genus has been shown to produce metabolites that are effective only against 
pathogenic bacteria $[64,65]$. However, Lophiostoma corticola had a degree of antagonism of level ' 1 ' against Fusarium solani and Mucor plumbeus and therefore zero antifungal activity. For such a questionable result, it would be ideal to perform antifungal tests with other phytopathogens to detect the antifungal activity of this genus. When we continue with the antifungal results from isolates connected with canes and leaves, the highest activity against Fusarium solani was detected in two isolates of the genus Aspergillus, Aspergillus niger and Aspergillus fumigatus. Aspergillus niger was the only species to show the highest activity also against Mucor plumbeus. Antifungal activity against the phytopathogens Giberella zeae, Thanatephorus cucumeris and six other nonpathogenic microscopic fungi was detected in the endophyte Aspergillus fumigatus isolated from Hyoscyamus muticus [66]. Aspergillus flavus, an endophyte of Lannea coromandelica, showed high antifungal activity against Candida albicans and Malassezia pachydermis. Aspergillus niger isolated from the same host plant showed a moderate ability to form antifungal metabolites against the mentioned phytopathogens [67]. From the mentioned studies, it can be concluded that the antifungal activity of the genus Aspergillus is high, which is in accordance with our results. The genus Penicillium is known for its antifungal effect on Botrytis cinerea $[7,68,69]$ and also shows this effect on Fusarium sp. [70,71]. Penicillium crustosum isolates from berries confirmed these findings, as they exhibited high antifungal activity against both Botrytis cinerea and Fusarium solani.

\section{Conclusions}

The population of endophytic fungi of Vitis vinifera has proven to be a promising source of growth-promoting and protective properties useful for the plant. Further studies are needed to investigate endophytic fungi in detail as a potential source of secondary metabolites. As it is a very poorly researched source of metabolites, it would be interesting to use the findings of this research work, choose the most productive endophytic species, and conduct detailed research. A closer focus on the formation of siderophores could be very useful in conjunction with enhancement of plant growth and biocontrol against phytopathogens. The study of antifungal metabolites could be used to develop effective biopesticides that could be a more environmentally friendly option for both the plant and the environment.

Author Contributions: Conceptualization, I.K., P.L. and M.K. (Markéta Kulišová); methodology, P.L., I.K., M.K. (Miroslav Kolař́ik) and B.V.; formal analysis, M.K. (Markéta Kulišová) and I.K.; investigation, M.K. (Markéta Kulišová), B.V., M.V. and M.K. (Miroslav Kolařík); resources, P.L., M.S. and I.K.; data curation, M.K. (Markéta Kulišová), M.V., P.L. and I.K.; writing-original draft preparation, M.K. (Markéta Kulišová) and M.S.; writing-review and editing, M.K. (Markéta Kulišová); visualization, M.K. (Markéta Kulišová) and M.V.; supervision, P.L. and I.K.; project administration, I.K. and M.S. All authors have read and agreed to the published version of the manuscript.

Funding: This research was funded by The Czech Science Foundation (GACR), grant number 18-26463S.

Institutional Review Board Statement: Not applicable.

Informed Consent Statement: Not applicable.

Acknowledgments: We acknowledge Pavel Bulánek for the possibility of collecting Vitis vinifera samples on vineyards in Prague and Stanislav Rudolfský on vineyards in Kutna Hora.

Conflicts of Interest: The authors declare no conflict of interest.

\section{References}

1. Kolouchová, I.; Melzoch, K.; Šmidrkal, J.; Filip, V. The content of resveratrol in vegetables and fruit. Chem. Listy 2005, 99, 492-495.

2. Schulz, B. Mutualistic interactions with fungal root endophytes. In Microbial Root Endophytes; Springer: Berlin/Heidelberg, Germany, 2006; pp. 261-279.

3. Maheshwari, D.K.; Maheshwari, R.; Rinaudo. Endophytes: Biology and Biotechnology; Springer: Berlin/Heidelberg, Germany, 2017. 
4. Kusari, S.; Hertweck, C.; Spiteller, M. Chemical ecology of endophytic fungi: Origins of secondary metabolites. Chem. Biol. 2012, 19, 792-798. [CrossRef]

5. Yadav, A.N.; Singh, S.; Mishra, S.; Gupta, A. Recent Advancement in White Biotechnology through Fungi; Springer: Berlin/Heidelberg, Germany, 2019.

6. González, V.; Tello, M.L. The endophytic mycota associated with V itis vinifera in central Spain. Fungal Divers. 2011, 47, 29-42. [CrossRef]

7. Toghueo, R.M.K.; Boyom, F.F. Endophytic Penicillium species and their agricultural, biotechnological, and pharmaceutical applications. 3 Biotech 2020, 10, 107. [CrossRef]

8. Gupta, S.; Chaturvedi, P.; Kulkarni, M.G.; Van Staden, J. A critical review on exploiting the pharmaceutical potential of plant endophytic fungi. Biotechnol. Adv. 2020, 39, 107462. [CrossRef]

9. Dina, B.; Mamtaj, S. Endophytic microorganisms: Colonization, plant-microbe interaction, diversity and their Bioprospecting. Res. J. Biotechnol. 2020, 15, 151-179.

10. Zimowska, B.; Bielecka, M.; Abramczyk, B.; Nicoletti, R. Bioactive products from endophytic fungi of sages (Salvia spp.). Agriculture 2020, 10, 543. [CrossRef]

11. Yadav, G.; Meena, M. Bioprospecting of endophytes in medicinal plants of Thar Desert: An attractive resource for biopharmaceuticals. Biotechnol. Rep. 2021, 30, e00629. [CrossRef] [PubMed]

12. Choudhary, M.; Gupta, S.; Dhar, M.K.; Kaul, S. Endophytic Fungi-Mediated Biocatalysis and Biotransformations Paving the Way Toward Green Chemistry. Front. Bioeng. Biotechnol. 2021, 9, 419. [CrossRef]

13. Ntemafack, A.; Kapoor, N.; Ali, S.; Jamwal, V.L.; Hassan, Q.P.; Gandhi, S.G. Comprehensive Review of Endophytic Flora from African Medicinal Plants. Curr. Microbiol. 2021, 78, 2860-2898. [CrossRef]

14. Ancheeva, E.; Daletos, G.; Proksch, P. Bioactive secondary metabolites from endophytic fungi. Curr. Med. Chem. 2020, 27, 1836-1854. [CrossRef] [PubMed]

15. Tan, R.X.; Zou, W.X. Endophytes: A rich source of functional metabolites. Nat. Prod. Rep. 2001, 18, 448-459. [CrossRef]

16. Górska, A.; Sloderbach, A.; Marszałł, M.P. Siderophore-drug complexes: Potential medicinal applications of the 'Trojan horse'strategy. Trends Pharmacol. Sci. 2014, 35, 442-449. [CrossRef] [PubMed]

17. El-Tarabily, K.A.; Sivasithamparam, K. Potential of yeasts as biocontrol agents of soil-borne fungal plant pathogens and as plant growth promoters. Mycoscience 2006, 47, 25-35. [CrossRef]

18. Schena, L.; Ippolito, A.; Zahavi, T.; Cohen, L.; Nigro, F.; Droby, S. Genetic diversity and biocontrol activity of Aureobasidium pullulans isolates against postharvest rots. Postharvest Biol. Technol. 1999, 17, 189-199. [CrossRef]

19. Schena, L.; Nigro, F.; Pentimone, I.; Ligorio, A.; Ippolito, A. Control of postharvest rots of sweet cherries and table grapes with endophytic isolates of Aureobasidium pullulans. Postharvest Biol. Technol. 2003, 30, 209-220. [CrossRef]

20. Sullivan, R.F.; White, J.F., Jr. Phoma glomerata as a mycoparasite of powdery mildew. Appl. Environ. Microbiol. 2000, 66, 425-427. [CrossRef]

21. Zhao, X.; Hu, Z.; Hou, D.; Xu, H.; Song, P. Biodiversity and antifungal potential of endophytic fungi from the medicinal plant Cornus officinalis. Symbiosis 2020, 81, 223-233. [CrossRef]

22. Aleynova, O.A.; Suprun, A.R.; Nityagovsky, N.N.; Dubrovina, A.S.; Kiselev, K.V. The Influence of the Grapevine Bacterial and Fungal Endophytes on Biomass Accumulation and Stilbene Production by the In Vitro Cultivated Cells of Vitis amurensis Rupr. Plants 2021, 10, 1276. [CrossRef] [PubMed]

23. Mondello, V.; Spagnolo, A.; Larignon, P.; Clement, C.; Fontaine, F. Phytoprotection potential of Fusarium proliferatum for control of Botryosphaeria dieback pathogens in grapevine. Phytopathol. Mediterr. 2019, 58, 293-306.

24. Shi, J.; Zeng, Q.; Liu, Y.; Pan, Z. Alternaria sp. MG1, a resveratrol-producing fungus: Isolation, identification, and optimal cultivation conditions for resveratrol production. Appl. Microbiol. Biotechnol. 2012, 95, 369-379. [CrossRef]

25. Yang, M.-Z.; Ma, M.-D.; Yuan, M.-Q.; Huang, Z.-Y.; Yang, W.-X.; Zhang, H.-B.; Huang, L.-H.; Ren, A.-Y.; Shan, H. Fungal Endophytes as a Metabolic Fine-Tuning Regulator for Wine Grape. PLoS ONE 2016, 11, e0163186. [CrossRef] [PubMed]

26. Kolařík, M.; Spakowicz, D.J.; Gazis, R.; Shaw, J.; Kubátová, A.; Nováková, A.; Chudíčková, M.; Forcina, G.C.; Kang, K.W.; Kelnarová, I. Biatriospora (Ascomycota: Pleosporales) is an ecologically diverse genus including facultative marine fungi and endophytes with biotechnological potential. Plant Syst. Evol. 2017, 303, 35-50. [CrossRef]

27. Píchová, K.; Pažoutová, S.; Kostovčík, M.; Chudíčková, M.; Stodůlková, E.; Novák, P.; Flieger, M.; van der Linde, E.; Kolařík, M. Evolutionary history of ergot with a new infrageneric classification (Hypocreales: Clavicipitaceae: Claviceps). Mol. Phylogenet. Evol. 2018, 123, 73-87. [CrossRef] [PubMed]

28. Marques, A.P.; Pires, C.; Moreira, H.; Rangel, A.O.; Castro, P.M. Assessment of the plant growth promotion abilities of six bacterial isolates using Zea mays as indicator plant. Soil Biol. Biochem. 2010, 42, 1229-1235. [CrossRef]

29. Fidler, M.; Kolářová, L. Analýza antioxidantů v chmelu a pivu. Chem. Listy 2009, 103, 232-235.

30. Bell, D.; Wells, H.; Markham, C. In vitro antagonism of Trichoderma species against six fungal plant pathogens. Phytopathology 1982, 72, 379-382. [CrossRef]

31. Aly, A.H.; Debbab, A.; Proksch, P. Fungal endophytes: Unique plant inhabitants with great promises. Appl. Microbiol. Biotechnol. 2011, 90, 1829-1845. [CrossRef] 
32. Núñez-Trujillo, G.; Cabrera, R.; Burgos-Reyes, R.; Silva, E.d.; Giménez, C.; Cosoveanu, A.; Brito, N. Endophytic fungi from Vitis vinifera L. isolated in Canary Islands and Azores as potential biocontrol agents of Botrytis cinerea Pers.: Fr. J. Hortic. For. Biotechnol. 2012, 16, 1-6.

33. Muvea, A.M.; Subramanian, S.; Maniania, N.K.; Poehling, H.-M.; Ekesi, S.; Meyhöfer, R. Endophytic colonization of onions induces resistance against viruliferous thrips and virus replication. Front. Plant Sci. 2018, 9, 1785. [CrossRef]

34. Varanda, C.M.R.; Oliveira, M.; Materatski, P.; Landum, M.; Clara, M.I.E.; do Rosário Félix, M. Fungal endophytic communities associated to the phyllosphere of grapevine cultivars under different types of management. Fungal Biol. 2016, 120, 1525-1536. [CrossRef] [PubMed]

35. Araújo, A.S.; Leite, L.F.; Santos, V.B.; Carneiro, R.F. Soil microbial activity in conventional and organic agricultural systems. Sustainability 2009, 1, 268-276. [CrossRef]

36. Xia, Y.; Sahib, M.R.; Amna, A.; Opiyo, S.O.; Zhao, Z.; Gao, Y.G. Culturable endophytic fungal communities associated with plants in organic and conventional farming systems and their effects on plant growth. Sci. Rep. 2019, 9, 1-10.

37. Geissen, V.; Silva, V.; Lwanga, E.H.; Beriot, N.; Oostindie, K.; Bin, Z.; Pyne, E.; Busink, S.; Zomer, P.; Mol, H. Cocktails of pesticide residues in conventional and organic farming systems in Europe-Legacy of the past and turning point for the future. Environ. Pollut. 2021, 278, 116827. [CrossRef]

38. Burns, K.N.; Kluepfel, D.A.; Strauss, S.L.; Bokulich, N.A.; Cantu, D.; Steenwerth, K.L. Vineyard soil bacterial diversity and composition revealed by $16 \mathrm{~S}$ rRNA genes: Differentiation by geographic features. Soil Biol. Biochem. 2015, 91, 232-247. [CrossRef]

39. Wilson, D. Endophyte: The evolution of a term, and clarification of its use and definition. Oikos 1995, 73, 274-276. [CrossRef]

40. Suryanarayanan, T.; Murali, T.; Venkatesan, G. Occurrence and distribution of fungal endophytes in tropical forests across a rainfall gradient. Can. J. Bot. 2002, 80, 818-826. [CrossRef]

41. Bacon, C.W.; White, J. Microbial Endophytes; CRC Press: Boca Raton, FL, USA, 2000.

42. Sarsaiya, S.; Jain, A.; Jia, Q.; Fan, X.; Fuxing, S.; Chen, Z.; Zhou, Q.; Shi, J.; Chen, J. Molecular Identification of Endophytic Fungi and Their Pathogenicity Evaluation Against Dendrobium nobile and Dendrobium officinale. Int. J. Mol. Sci. 2020, 21, 316. [CrossRef]

43. Wijekoon, C.; Quill, Z. Fungal endophyte diversity in table grapes. Can. J. Microbiol. 2021, 67, 29-36. [CrossRef]

44. Jayawardena, R.S.; Purahong, W.; Zhang, W.; Wubet, T.; Li, X.; Liu, M.; Zhao, W.; Hyde, K.D.; Liu, J.; Yan, J. Biodiversity of fungi on Vitis vinifera L. revealed by traditional and high-resolution culture-independent approaches. Fungal Divers. 2018, 90, 1-84. [CrossRef]

45. Matsuoka, H.; Akiyama, M.; Kobayashi, K.; Yamaji, K. Fe and P solubilization under limiting conditions by bacteria isolated from Carex kobomugi roots at the Hasaki coast. Curr. Microbiol. 2013, 66, 314-321. [CrossRef]

46. Haas, H. Fungal siderophore metabolism with a focus on Aspergillus fumigatus. Nat. Prod. Rep. 2014, 31, 1266-1276. [CrossRef]

47. Sharma, H.; Rai, A.K.; Chettri, R.; Nigam, P.S. Bioactivites of Penicillium citrinum isolated from a medicinal plant Swertia chirayita. Arch. Microbiol. 2021, 203, 5173-5182. [CrossRef]

48. Chowdappa, S.; Jagannath, S.; Konappa, N.; Udayashankar, A.C.; Jogaiah, S. Detection and Characterization of Antibacterial Siderophores Secreted by Endophytic Fungi from Cymbidium aloifolium. Biomolecules 2020, 10, 1412. [CrossRef]

49. Huang, W.-Y.; Cai, Y.-Z.; Xing, J.; Corke, H.; Sun, M. A potential antioxidant resource: Endophytic fungi from medicinal plants. Econ. Bot. 2007, 61, 14-30. [CrossRef]

50. Nischitha, R.; Shivanna, M. Metabolite fingerprinting, in vitro antimicrobial and antioxidant activities and in-silico docking in Alloteropsis cimicina and its endophytic fungus Penicillium pinophilum. Mol. Biol. Rep. 2021, 48, 4021-4037. [CrossRef]

51. Arora, D.S.; Chandra, P. Antioxidant activity of Aspergillus fumigatus. Int. Sch. Res. Not. 2011, 2011, 619395. [CrossRef] [PubMed]

52. Sharaf, M.H.; Abdelaziz, A.M.; Kalaba, M.H.; Radwan, A.A.; Hashem, A.H. Antimicrobial, Antioxidant, Cytotoxic Activities and Phytochemical Analysis of Fungal Endophytes Isolated from Ocimum Basilicum. Appl. Biochem. Biotechnol. 2021, 1-19. [CrossRef] [PubMed]

53. Vellingiri, M.M.; Ashwin, J.K.M.; Soundari, A.J.P.G.; Sathiskumar, S.; Priyadharshini, U.; Paramasivam, D.; Liu, W.-C.; Balasubramanian, B. Mycofabrication of AgONPs derived from Aspergillus terreus FC36AY1 and its potent antimicrobial, antioxidant, and anti-angiogenesis activities. Mol. Biol. Rep. 2021, 48, 7933-7946. [CrossRef] [PubMed]

54. Kumari, P.; Singh, A.; Singh, D.K.; Sharma, V.K.; Kumar, J.; Gupta, V.K.; Bhattacharya, S.; Kharwar, R. Isolation and purification of bioactive metabolites from an endophytic fungus Penicillium citrinum of Azadirachta indica. S. Afr. J. Bot. 2021, 139, 449-457. [CrossRef]

55. Devi, N.; Prabakaran, J. Bioactive metabolites from an endophytic fungus Penicillium sp. isolated from Centella asiatica. Curr. Res. Environ. Appl. Mycol. 2014, 4, 34-43. [CrossRef]

56. Kaur, R.; Kaur, J.; Kaur, M.; Kalotra, V.; Chadha, P.; Kaur, A.; Kaur, A. An endophytic Penicillium oxalicum isolated from Citrus limon possesses antioxidant and genoprotective potential. J. Appl. Microbiol. 2020, 128, 1400-1413. [CrossRef]

57. Nasrin, M.; Afroz, F.; Begum, M.N.; Rony, S.R.; Sharmin, S.; Moni, F.; Rana, M.S.; Sohrab, M.H. Isolation and Bioactivity Screening of Endophytic Fungi from Commelina diffusa. Indian J. Pharm. Educ. Res. 2021, 55, 829-836. [CrossRef]

58. Kumar, V.; Prasher, I. Phytochemical analysis and antimicrobial potential of Nigrospora sphaerica (Berk. \& Broome) Petch, a fungal endophyte isolated from Dillenia indica L. Adv. Tradit. Med. 2021, 1-13. [CrossRef]

59. Acuña-Rodríguez, I.S.; Newsham, K.K.; Gundel, P.E.; Torres-Díaz, C.; Molina-Montenegro, M.A. Functional roles of microbial symbionts in plant cold tolerance. Ecol. Lett. 2020, 23, 1034-1048. [CrossRef] 
60. Monggoot, S.; Popluechai, S.; Gentekaki, E.; Pripdeevech, P. Fungal endophytes: An alternative source for production of volatile compounds from agarwood oil of Aquilaria subintegra. Microb. Ecol. 2017, 74, 54-61. [CrossRef] [PubMed]

61. Hamilton, C.E.; Bauerle, T.L. A new currency for mutualism? Fungal endophytes alter antioxidant activity in hosts responding to drought. Fungal Divers. 2012, 54, 39-49. [CrossRef]

62. Gams, W.; Anderson, T.-H. Compendium of Soil Fungi; Academic Press: Cambridge, MA, USA, 1980.

63. Pitt, J.I.; Hocking, A.D. Fungi and Food Spoilage; Springer: Berlin/Heidelberg, Germany, 2009; Volume 519.

64. Mao, Z.; Xue, M.; Gu, G.; Wang, W.; Li, D.; Lai, D.; Zhou, L. Lophiostomin A-D: New 3, 4-dihydroisocoumarin derivatives from the endophytic fungus Lophiostoma sp. Sigrf10. RSC Adv. 2020, 10, 6985-6991. [CrossRef]

65. Shushni, M.A.M.; Azam, F.; Lindequist, U. Oxasetin from Lophiostoma sp. of the Baltic Sea: Identification, in silico binding mode prediction and antibacterial evaluation against fish pathogenic bacteria. Nat. Prod. Commun. 2013, 8, 193. [CrossRef]

66. Abdel-Motaal, F.F.; Nassar, M.S.; El-Zayat, S.A.; El-Sayed, M.A.; Ito, S.I. Antifungal activity of endophytic fungi isolated from Egyptian henbane (Hyoscyamus muticus L.). Pak. J. Bot. 2010, 42, 2883-2894.

67. Premjanu, N.; Jaynthy, C.; Diviya, S. Antifungal activity of endophytic fungi isolated from lannea coromandelica-an insilico approach. Int. J. Pharm. Pharm. Sci. 2016, 8, 207-210.

68. Rouissi, W.; Ugolini, L.; Martini, C.; Lazzeri, L.; Mari, M. Control of Postharvest Fungal Pathogens by Antifungal Compounds from Penicillium expansum. J. Food Prot. 2013, 76, 1879-1886. [CrossRef]

69. Li, H.; Wei, J.; Pan, S.-Y.; Gao, J.-M.; Tian, J.-M. Antifungal, phytotoxic and toxic metabolites produced by Penicillium purpurogenum. Nat. Prod. Res. 2014, 28, 2358-2361. [CrossRef] [PubMed]

70. Korejo, F.; Ali, S.A.; Shafique, H.A.; Sultana, V.; Ara, J.; Ehteshamul-Haque, S. Antifungal and antibacterial activity of endophytic Penicillium species isolated from Salvadora species. Pak. J. Bot. 2014, 46, 2313-2318.

71. Urooj, F.; Farhat, H.; Ali, S.A.; Ahmed, M.; Sultana, V.; Shams, Z.I.; Ara, J.; Ehteshamul-Haque, S. Role of endophytic Penicillium species in suppressing the root rotting fungi of sunflower. Pak. J. Bot. 2018, 50, 1621-1628. 